\title{
Dynamics of physicochemical indicators using various fertilization systems on sod-podzolic sandy loam soil and their Influence on Crop Productivity
}

\author{
Tamara Volodina*, Igor Pavlov, and Olga Nazarova
}

Federal State Budgetary Educational Institution of Higher Education Velikie Luki State Agricultural Academy, 182112, 2, Lenin, av., Velikiye Luki, Pskov region, Russian Federation

\begin{abstract}
As a result of the studies carried out by the Department of Chemistry, Agrochemistry and Agroecology to improve the physicochemical parameters of sod-podzolic soils in the conditions of the Pskov region, positive results were obtained. It was noted that on the sodpodzolic sandy loam soil in the period from 2016 to 2019 , in the control option, there was a gradual increase in soil acidity over the years. For 5 years, the exchange acidity increased by 0.1 units, and the hydrolytic acidity of the soil by $0.07 \mathrm{meq} / 100 \mathrm{~g}$ of soil. Against the background with mineral fertilizers, as well as in the control, during the study period there was no decrease in the value of exchangeable acidity, and the increase in hydrolytic acidity was not significant by $0.02 \mathrm{meq} / 100 \mathrm{~g}$ of soil, respectively, in relation to 2016. Application of manure in the amount of 30 and $40 \mathrm{t} / \mathrm{ha}$ contributed to a significant improvement in the acid-base state of the soil. During the years under study, exchangeable acidity decreased by $0.7-1.1$ units (from 5.8 to 6.1 units), and the hydrolytic acidity of the soil decreased by $0.08 \mathrm{meq} / 100 \mathrm{~g}$ of soil due to the influx of stubble-root residues. Application of manure reduced the negative indicators of the $\mathrm{Ca}$ and $\mathrm{Mg}$ balance by $564 \mathrm{~kg} / \mathrm{ha}$ or by $83 \%$, and in the organomineral and mineral options only by 64 and $39 \%$, respectively. The results of studies on sandy loamy sod-podzolic soil also showed a high efficiency of the influence of fertilization systems on the productivity of crops in the crop rotation link. The best performance indicators were obtained from the organomineral fertilization system.
\end{abstract}

\section{Introduction}

Sod-podzolic soils form the basis of the arable fund of the Non-Chernozem zone of Russia. Most of them are characterized by unsatisfactory physicochemical properties. The main way to regulate the acidity of sod-podzolic soils is the introduction of various lime materials, one of which is limestone flour. The light mechanical composition of sandy loam soils, poor humus, nitrogen and mobile forms of phosphorus and potassium, require the

\footnotetext{
*Corresponding author: toma230547@yandex.ru
} 
obligatory introduction of organic and mineral fertilizers, and with excessive acidity and small doses of lime. Without a good filling with organic matter, it is difficult to get high yields on them $[5,9,10,20]$.

Organic fertilizers can also act as regulators of the acid-base properties of soils $[6,8$, 17]. Due to the reduction in use of mineral fertilizers acidifying the soil, the general rate of acidification of Russian lands may slow down, but this stagnation is temporary. The positive effect of manure is due to the fact that it has an almost neutral reaction, and is also a source of calcium and magnesium, which help to neutralize soil acidity and improve its structural state [8].

Many crops are sensitive to increased soil acidity and are very responsive to methods of neutralizing it. The acidic reaction of sod-podzolic soils is their stable feature. The acid reaction has a harmful effect on the physicochemical and biological processes in the soil and physiological in plants. The harmful effect of the acidic reaction of the soil is associated with the toxicity of hydrogen ions and mobile aluminum $[1,18]$. In this regard, it became necessary to study the regularity and nature of changes in the acid-base properties of sandy loamy sod-podzolic soil when using various fertilization systems and their impact on the productivity of agricultural crops. Therefore, we believe that this topic is timely and relevant.

The aim of the study is to establish the influence of various fertilization systems on the physicochemical parameters of sod-podzolic sandy loam soil, which ensure extended reproduction of soil fertility and stable productivity of agricultural crops.

Study objectives:

- study of the ecological and agrochemical state of sod-podzolic soils (field studies are aimed at determining the dynamics of the physicochemical properties of the soil);

- determination of the optimal fertilization system, allowing to obtain a high yield of agricultural crops.

\section{Methods}

The studies were carried out on an experimental field in the village of Maikino of Federal State-Owned Publicly-Funded Institution of Higher Education Velikie Luki State Agricultural Academy. The Maikino experimental field is located in the Velikoluksky district of the Pskov region and is part of the North-West economic region of the NonBlack Earth Zone of Russia. The territory of the economy is located on the Lovatskaya lowland. The soils of the experimental field are mainly sod-weak and medium-podzolic loams, and sandy loams, average soil cultivation. The soil of the experimental land plot within the arable layer before laying was characterized by an average humus supply of 1.8$1.95 \%$, a weakly acidic $\mathrm{pH}$ salt reaction -5.1 units, with a satisfactory degree of saturation with bases $82 \%$. According to the content of mobile compounds of phosphorus and potassium 141 and $121 \mathrm{mg} / \mathrm{kg}$, respectively. According to the classification of N.L. Blagovidov, soil with such agrochemical properties shall be considered as medium-cultivated.

Field experiment with various fertilization systems was laid on sod-podzolic sandy loam soil in 2016 according to the following scheme: Without fertilizers; 2. Manure of $70 \mathrm{t} / \mathrm{ha} ; 3$. Manure $70 \mathrm{t} / \mathrm{ha}+\mathrm{N}_{120} \mathrm{P}_{90} \mathrm{~K}_{120} ; 4 . \mathrm{N}_{120} \mathrm{P}_{90} \mathrm{~K}_{120}$

The field experiment was carried out in triplicate, total area $32 \mathrm{~m}^{2}$, counting- $31.6 \mathrm{~m}^{2}$. The experiment used the following types of fertilizers: organic - semi-rotted cattle manure; mineral - ammonium nitrate, double superphosphate, potassium chloride. Organic fertilizers were applied for potatoes, and mineral fertilizers were applied according to the experimental scheme in the spring before sowing for pre-sowing soil cultivation. 
In the experiment, the following crops were sown: potatoes (variety Red Scarlet), spring wheat (variety Moskovskaya 35), white mustard (variety Rapsodiya) for green mass and green manure, winter wheat (variety Skipiter).

Counting of the harvest was carried out using a continuous gravimetric method. Before harvesting, plant samples were taken to determine the structure and quality of the crop. In the selected samples, agrochemical analyzes of the soil were carried out in two, three times in the analytical laboratory of the Velikie Luki State Agricultural Academy and in the laboratories of the station of the agrochemical service Velikolukskaya according to the methodological guidelines recommended for the zone.

Meteorological conditions have a significant impact on the efficiency of fertilizers. Summarizing 20 years of experimental data, I.A. Ivanov (1998) [7] came to the conclusion that in the conditions of the North-West the best yields and their greatest additions from fertilizers are provided under meteorological conditions close to the average annual, or with a slight deviation towards aridity.

In the years under study, throughout the growing season, all climatic indicators are close to the average long-term values, which made it possible to form a good level of yield of cultivated crops.

\section{Results}

Our study on soddy-podzolic sandy loam soil showed that in the control option there was a tendency towards an increase in exchangeable acidity, over the years of study it was 0.1 0.2 units.

In the option with a mineral fertilization system, by the end of the study, a decrease in exchangeable acidity did not occur due to use of optimal doses of fertilizers and an increase in supply of stubble-root residues.

In 2016-2019, acidity indicators increased in options with an organic and organomineral system. In 2017, the indicators of exchangeable acidity were 5.9-6.1 units, that is, it reached a neutral reaction for sod-podzolic soils. In these options, the effect of the action of manure applied for potatoes, as well as its aftereffect on subsequent crops, was well traced. Stubbleroot residues are also of great importance, introducing although a small amount of $\mathrm{Ca}$ and $\mathrm{Mg}$ into the soil, but having a certain effect on the physicochemical properties of soils.

\section{Discussion}

In the option with manure in the above-mentioned period, the value of exchangeable acidity decreased at the end of the growing season to a $\mathrm{pH}$ of 5.8-6.1 units. In the option with the organomineral fertilization system, the results on improving the acidity of the soil were similar to the option with manure. Although the magnitude of the rise in acidity could be higher in comparison with the organic background of nutrition, which, apparently, is explained by the insignificant effect of mineral fertilizers, both in action and in aftereffect (Table 1). 
Table 1. Dynamics of changes in the basic physical and chemical properties of sod-podzolic sandy loam soil.

\begin{tabular}{|c|c|c|c|c|c|c|c|c|c|c|}
\hline \multirow[t]{2}{*}{ Option } & \multicolumn{4}{|c|}{$\begin{array}{l}\text { The beginning of the } \\
\text { growing season }\end{array}$} & \multirow{2}{*}{$\begin{array}{c}\text { Averag } \\
\text { e } \\
\text { for } \\
2016- \\
2019 \\
\end{array}$} & \multicolumn{4}{|c|}{ End of vegetation } & \multirow{2}{*}{$\begin{array}{c}\text { Averag } \\
\text { e for } \\
2016- \\
2019\end{array}$} \\
\hline & $\begin{array}{l}201 \\
6\end{array}$ & $\begin{array}{l}201 \\
7\end{array}$ & $\begin{array}{l}201 \\
8\end{array}$ & $\begin{array}{l}201 \\
9\end{array}$ & & $\begin{array}{l}201 \\
6\end{array}$ & $\begin{array}{l}201 \\
7\end{array}$ & $\begin{array}{l}201 \\
8\end{array}$ & $\begin{array}{l}201 \\
9\end{array}$ & \\
\hline \multicolumn{11}{|c|}{ pHsal. } \\
\hline Control & 5.20 & 5.25 & 5.15 & 5.10 & 5.17 & 5.10 & 5.20 & 5.10 & 5.00 & 5.10 \\
\hline $\begin{array}{l}\text { Manure } \\
70 \mathrm{t} / \mathrm{ha}\end{array}$ & 5.60 & 5.88 & 5.92 & 5.80 & 5.80 & 5.88 & 6.10 & 5.85 & 5.75 & 5.89 \\
\hline $\begin{array}{l}\text { Manure } \\
40 t / h a+ \\
\mathrm{N}_{120} \mathrm{P}_{90} \\
\mathrm{~K}_{120}\end{array}$ & 5.50 & 5.82 & 5.86 & 5.80 & 5.74 & 5.80 & 5.94 & 5.83 & 5.82 & 5.85 \\
\hline $\begin{array}{c}\mathrm{N}_{120} \mathrm{P}_{90} \mathrm{~K}_{12} \\
0\end{array}$ & 5.30 & 5.2 & 5.25 & 5.15 & 5.22 & 5.20 & 5.10 & 5.20 & 5.1 & 5.15 \\
\hline \multicolumn{11}{|c|}{$\mathrm{Ng}$} \\
\hline Control & 1.43 & 1.42 & 1.46 & 1.48 & 1.45 & 1.40 & 1.44 & 1.46 & 1.5 & 1.45 \\
\hline $\begin{array}{l}\text { Manure } \\
70 \mathrm{t} / \mathrm{ha}\end{array}$ & 1.23 & 0.95 & 0.90 & 1.13 & 1.05 & 1.06 & 0.85 & 0.97 & 0.93 & 0.95 \\
\hline $\begin{array}{l}\text { Manure } \\
70 \mathrm{t} / \mathrm{ha}+ \\
\mathrm{N}_{120} \mathrm{P}_{90} \mathrm{~K}_{12} \\
0\end{array}$ & 1.12 & 0.97 & 1.07 & 1.15 & 1.08 & 0.99 & 0.91 & 1.11 & 1.11 & 1.03 \\
\hline $\begin{array}{c}\mathrm{N}_{120} \mathrm{P}_{90} \mathrm{~K}_{12} \\
0\end{array}$ & 1.37 & 1.38 & 1.36 & 1.42 & 1.38 & 1.40 & 1.42 & 1.40 & 1.44 & 1.41 \\
\hline
\end{tabular}

On the mineral fertilization system, there is a slight tendency towards a decrease in soil acidity, however, its deviations in one direction or another ranged within 0.05-0.2 units higher than the control at the beginning and at the end of the growing season, which does not confirm the opinion of scientists about the negative effect of mineral fertilizers.

The second most important indicator characterizing the acid-base properties of sodpodzolic soil is hydrolytic acidity $\left(\mathrm{H}_{\mathrm{g}}\right)$.

We have noted a direct relationship between exchange and hydrolytic acidity. As shown by the results of our studies, with a decrease in exchangeable acidity, the value of hydrolytic acidity decreases (correlation coefficient $r=0.9562$ and 0.9886 ) and, conversely, with an increase in exchangeable acidity, hydrolytic acidity also increased.

A decrease in the indicators of hydrolytic acidity in the option with manure application in 2016 is observed to $1.23 \mathrm{mg}$-eq/100 g, and in the option with an organomineral fertilization system - to 1.12 due to the intake of calcium with manure and phosphorus fertilizers. When mineral fertilizers were applied, in comparison with the control option, the hydrolytic acidity fluctuated on average $1.37-1.41$ meq per $100 \mathrm{~g}$ of soil. Subsequently, this trend continues. This is explained by an increase in the productivity of agricultural crops in comparison with the control option, an increase in the mass of stubble-root residues, which, as we assume, led to an increase in the intake of calcium and magnesium during their decomposition. The leaching type of water regime, characteristic of our zone, has a direct effect on the acid-base properties of the soil. For this reason, the positive effect of the aftereffect of organic fertilizers is not very high, but a tendency towards an improvement in acid-base properties is observed. This is especially noticeable in the dynamics of exchangeable acidity. 
In general, we can note the tendency of the soil-absorbing complex to return the properties of the soil, especially against the background without fertilizers, to its original state in connection with the tendency of the soil solution to equilibrium, which is noticeable at the end of the growing season in the control option (Table 1).

Analyzing the effect and aftereffect of organic fertilizers, we noted that in the year of their application, the effect of a decrease in Нг is observed already by the end of the growing season due to the light mechanical composition of the soil and the accelerated occurrence of mineralization processes in them.

Therefore, the results of our studies have confirmed the importance of the participation of organic fertilizers in the regulation of exchange and hydrolytic acidity, which have a neutralizing effect on the indicated indicators of sod-podzolic soils.

However, for more significant changes in the physicochemical properties of sodpodzolic soils, it is necessary to use lime fertilizers in doses that maintain the existing level of acidity in the soil. In this regard, the efficiency of the applied fertilization systems will be much higher.

The total amount of all exchange-absorbed cations in the soil is the cation exchange capacity (CEC), or the absorption capacity. Its value characterizes the absorption capacity of soils. ECO depends on the granulometric and mineralogical composition of the soil, the total content of organic matter in it. The more mineral and organic colloidal particles in the soil, the higher its absorption capacity. The properties of the soil and the conditions for plant growth largely depend on the composition and size of the absorbed cations $[15,16$, $18,19]$.

The indices of the sum of absorbed bases presented in Table 2 increased markedly when all fertilization systems were applied. However, the highest indicator was obtained in the option with an organic and organomineral fertilization system. At the end of the season, it amounted to 6.3 and $6.1 \mathrm{meq} / 100 \mathrm{~g}$ of soil, respectively.

Due to the fact that a soil with an average degree of cultivation was chosen for the experiment, the initial indicators of the capacity of cation exchange and the degree of saturation with bases are low. In subsequent years of study, different types of fertilizers have different effects on these indicators.

In the control option, there is a tendency towards a decrease in CEC, which is a natural result associated with the removal of $\mathrm{Ca}$ and $\mathrm{Mg}$ with the harvest of field crops (Table 2).

Table 2. Capacity of cation exchange when using various fertilization systems on sandy loamy sodpodzolic soil.

\begin{tabular}{|c|c|c|c|}
\hline \multirow{2}{*}{ Option } & \multicolumn{3}{|c|}{$\begin{array}{c}\text { Indicators } \\
\mathrm{Ca}^{2} \text { and } \mathrm{Mg}^{2}, \mathrm{mg}-\mathrm{eq} / \mathbf{1 0 0} \mathrm{g}\end{array}$} \\
\hline & $\begin{array}{l}\text { April 19, } \\
2015\end{array}$ & September 06, 2017 & September 27, 2019 \\
\hline Control & 5.15 & 4.90 & 4.20 \\
\hline Manure $70 \mathrm{t} / \mathrm{ha}$ & 5.65 & 5.88 & 6.30 \\
\hline $\begin{array}{l}\text { Manure } 70 \mathrm{t} / \mathrm{ha}+ \\
\mathrm{N}_{120} \mathrm{P}_{90} \mathrm{~K}_{120}\end{array}$ & 5.78 & 5.92 & 6.10 \\
\hline $\mathrm{N}_{120} \mathrm{P}_{90} \mathrm{~K}_{120}$ & 5.45 & 5.55 & 5.54 \\
\hline
\end{tabular}

The introduction of $\mathrm{Ca}$ with phosphorus fertilizers stabilized its content at the same level, and in relation to the control option it was higher by $0.30-1.34 \mathrm{mg}$-eq./100 $\mathrm{g}$ of soil.

This confirms the assumption that manure, not being a direct source of $\mathrm{Ca}$, directly affects its content in the soil. In the option with an organomineral fertilization system in relation to pure manure, there was a slight increase in the amount of exchange bases, mainly due to the intake of $\mathrm{Ca}$ as with manure and phosphorus fertilizers. The largest increase in CEC occurred in the option with organic and organic mineral fertilization 
systems and amounted to 6.3 and $6.1 \mathrm{meq} / 100 \mathrm{~g}$ of soil, respectively. This pattern remains in accordance with changes in the indicators of acid-base properties of the soil.

The resulting high yield of cultivated crops contributed to an increase in the amount of exchange bases, since a lot of stubble-root residues entered the soil, which also contain $\mathrm{Ca}$ and $\mathrm{Mg}$.

The same pattern can be traced with respect to the degree of saturation with bases $\mathrm{V} \%$. In the control option, there was a gradual decrease in the value of V (by $3.2 \%$ over the study period). The dynamics of this indicator change in the option with mineral fertilizers was unstable. Apparently, the weather conditions of 2017-2018 affected, when the sum of exchange bases with upward currents accumulated during dry periods. Organic and organomineral fertilization systems to some extent increased the degree of saturation with soil bases in 2019 compared to 2016 by 4 and 3\%, respectively (Figure 1).

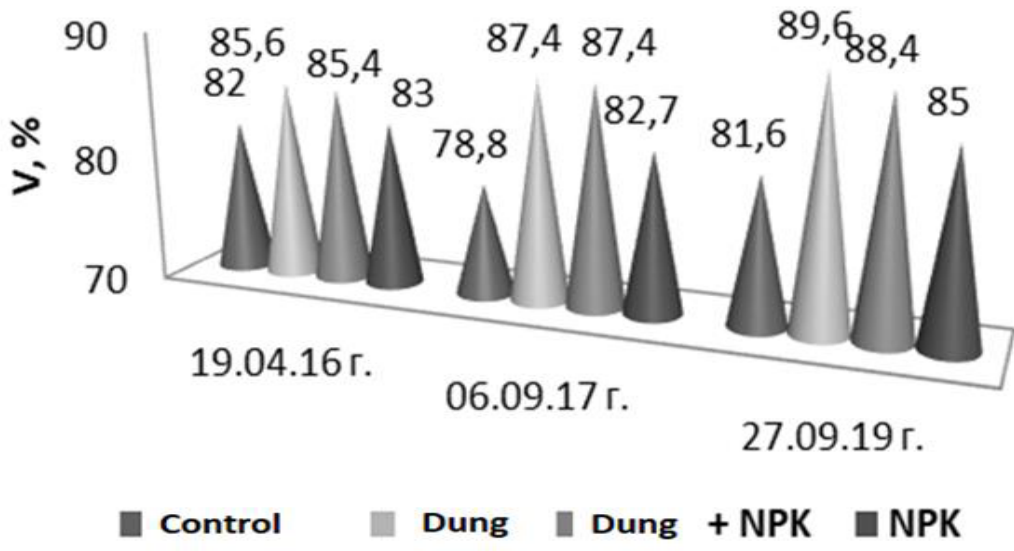

Fig.1. Change in the degree of saturation with bases when using various fertilization systems.

Therefore, the results presented in Tables 2 and in Figure 1 prove a sufficiently high efficiency of the organic and organomineral fertilization system in terms of their effect on the acid-base state of sod-podzolic sandy loam soils. All these changes in the acid-base state of the soil are very significant favorable factors for increasing soil fertility, and hence increasing the productivity of cultivated plants and the quality of crop production.

Calculation of the balance of calcium and magnesium has not yet become mandatory in the practice of evaluating fertilization systems in crop rotations. On the one hand, this can be explained by the presence of simpler criteria for predicting changes in the acid-base properties of the soil, on the other hand, by the incomplete development of the regulatory framework [4].

The removal of calcium and magnesium by crops, unlike other macronutrients, is not the main expense item in the balance sheet. With average yields, it is: for cereals - 15-25, flax and potatoes - 25-35, perennial grasses, most vegetables, fodder root crops, silage $50-80 \mathrm{~kg} / \mathrm{ha}$ (Figure 1). 


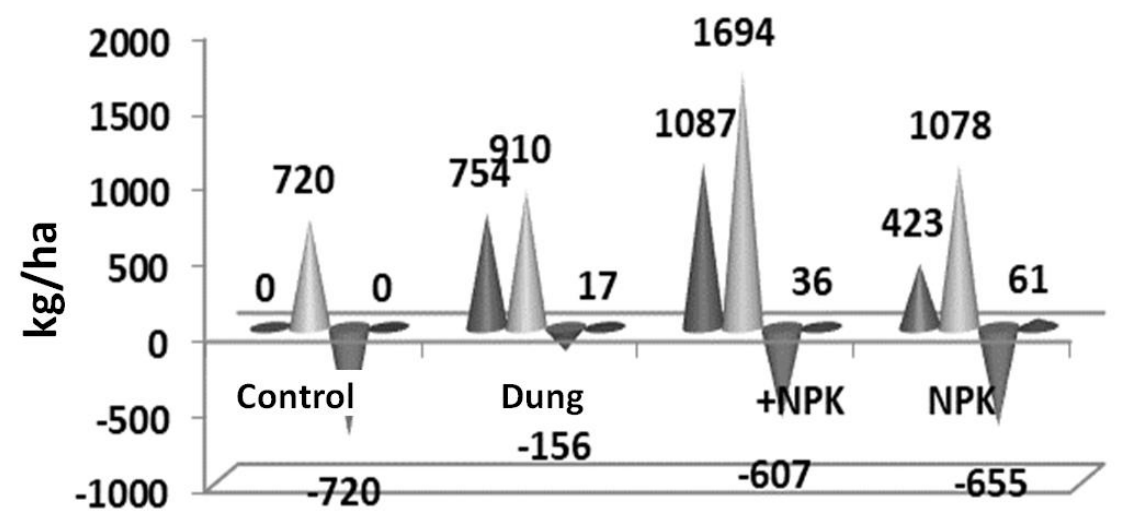

Fig. 2. Balance of $\mathrm{Ca}$ and $\mathrm{Mg}$ in the field crop rotation link, $\mathrm{kg} / \mathrm{ha}$.

The regularities here are as follows: the higher the soil $\mathrm{pH}$, the lighter its granulometric composition, the higher the dose of lime and acidic mineral fertilizers, the longer the frostfree period, the greater the losses from leaching [7].

As shown by the results shown in Figure 2, the balance of calcium and magnesium in the field crop rotation was sharply negative almost everywhere.

The application of manure reduced the negative indicators of the $\mathrm{Ca}$ and $\mathrm{Mg}$ balance by $564 \mathrm{~kg} / \mathrm{ha}$ or by $83 \%$, and in the organomineral and mineral options only by 64 and $39 \%$, respectively. This is confirmed by the study of scientists on the positive effect of manure, associated with the fact that it itself has an almost neutral reaction $(\mathrm{pH}=6.8)$, and is also a source of calcium and magnesium, which contribute to the neutralization of soil acidity and its structuring $[15,18]$.

However, it is possible to fully replenish the Ca influx into the soil only with the help of liming, and with an increase in the yield, the $\mathrm{Ca}$ removal also increases. The real $\mathrm{Ca}$ balance in all options was negative and was $70 \mathrm{t} / \mathrm{ha}$ per crop turnover. When comparing the effectiveness of different fertilization systems, the main criterion is the productivity of the cultivated crops.

According to experts, about half of the total yield increase is obtained through use of fertilizers, including organic ones. When crops are cultivated without fertilization, the plants deplete the soil and the productivity of the crops decreases. Use of organic systems as fertilizers increases the yield indicators $[2 ; 13]$. Many scientists have noted a rather long aftereffect of organic fertilizers even on the last crop rotation $[9,11]$.

The role and effectiveness of fertilizers in the Non-Chernozem zone, where favorable climatic conditions have developed (sufficient moisture, warm) for the growth and development of crops are of particularly importance. However, sod-podzolic soils are very poor in nature, have an acidic reaction of the environment, which is why they respond very well to use as a mineral and organic fertilizers [12].

Nitrogen plays a leading role in increasing crop productivity nym and organic fertilizers, and then phosphorus and potash, especially on cultivated soils. Long-term use of organic matter significantly reduces the content of mobile forms of $\mathrm{Al}, \mathrm{Mn}, \mathrm{Fe}$ in the soil due to their neutralization with $\mathrm{Ca}$ and $\mathrm{Mg}$ cations [2].

The results summed up over the years of research on the impact of various fertilizer systems on the productivity of potatoes, white mustard, spring wheat, winter wheat showed the formation of high crop yields in experiments (tables 3,4,5,6). The high efficiency of the combined use of organic and mineral fertilizers is evidenced by the experiments of 
N.M. Belous [2015]. The optimal doses of nitrogen for mid-ripening and late-ripening potato varieties range from 120 to $150 \mathrm{~kg} / \mathrm{ha}$, provided they are balanced with other nutrients. When applied with fertilizers $120 \mathrm{~kg}$ of nitrogen per $1 \mathrm{ha}$, on average, $50-60 \mathrm{~kg}$ of tubers are obtained per $1 \mathrm{~kg}$ of nitrogen. On light sandy loam soils with a sufficient amount of moisture, the efficiency can be even higher.

Potato yields in 2016 were generally satisfactory despite the dry conditions of the year (Table 3).

Table 3. Impact of different fertilization systems on potato yield, 2016.

\begin{tabular}{|l|c|c|c|}
\hline \multirow{2}{*}{ Option } & \multirow{2}{*}{$\begin{array}{c}\text { Average } \\
\text { yield, t/ha }\end{array}$} & \multicolumn{2}{c|}{ Increase } \\
\cline { 3 - 4 } & 2.9 & & t/ha \\
\hline Control & 33.1 & 8.92 & 35 \\
\hline Manure 70 t/ha & 41.2 & 17.04 & 78 \\
\hline $\begin{array}{l}\text { Manure } 70 \mathrm{t} / \mathrm{ha}+\mathrm{N}_{120} \mathrm{P} \\
90 \mathrm{~K}_{120}\end{array}$ & 33.0 & 8.40 & 25 \\
\hline $\mathrm{N}_{120} \mathrm{P}_{90} \mathrm{~K}_{120}$ & & 1.64 & \\
\hline $\mathrm{NSR}_{05}$ & & & \\
\hline
\end{tabular}

The analysis of the given data showed that the yield of the control level was obtained at the same level, i.e. the influence of the predecessor is smoothed out and the effect of fertilizers is manifested. However, the greatest efficiency was obtained in the option with the organomineral system and was significantly higher than in the other options. This excess fluctuated within the range of $25-78 \%$.

In recent years, spring wheat has been increasingly used in crop rotations in the NorthWest of Russia and quite successfully. The study of cultivation in our area of this crop does not have such a long history as winter rye or wheat. Despite this, the results obtained in the experiments showed its high productivity and plasticity of this culture. Spring wheat yields in 2017 were generally satisfactory despite the dry conditions of the year (Table 4).

Table 4. Influence of different fertilization systems on the yield of spring wheat, 2017.

\begin{tabular}{|l|c|c|c|}
\hline \multirow{2}{*}{ Option } & \multirow{2}{*}{$\begin{array}{c}\text { Average } \\
\text { yield, t/ha }\end{array}$} & \multicolumn{2}{c|}{ Increase } \\
\cline { 3 - 4 } & 2.6 & - & t/ha \\
\hline Control & 3.9 & 1.3 & 50 \\
\hline Manure * 70 t/ha & 4.4 & 1.8 & 69 \\
\hline $\begin{array}{l}\text { Manure * 70 t/ha + N } 120 \mathrm{P} \\
90 \mathrm{~K}_{120}\end{array}$ & 4.2 & 1.6 & 61 \\
\hline $\mathrm{N}_{120} \mathrm{P}_{90} \mathrm{~K}_{120}$ & & 0.36 & \\
\hline $\mathrm{NSR}_{05}$ & & & \\
\hline
\end{tabular}

* Manure - 1 year aftereffect.

The analysis of the given data showed that the yield of the control option was obtained at the same level, i.e. the influence of the predecessor is smoothed out and the effect of fertilizers is manifested. However, the greatest efficiency was obtained in the option with the organomineral system, and, despite the aftereffect of manure, it was significantly higher than in the other options. This excess fluctuated within the range of 50-69 \% (Table 6).

At present, the cultivation of white mustard as a green manure has become very popular. Given that cattle manure is a deficit in modern agriculture, it became necessary to replace it with another source of organic matter in the soil, which was green manure (Table 5).

Table 5. Influence of various fertilization systems on the yield of white mustard, 2018. 


\begin{tabular}{|l|c|c|c|}
\hline \multirow{2}{*}{ Option } & \multirow{2}{*}{$\begin{array}{c}\text { Average yield of } \\
\text { green mass, t/ha }\end{array}$} & \multicolumn{2}{c|}{ Increase, t/ha } \\
\cline { 3 - 4 } & 5.5 & t/ha & \% \\
\hline Control & 7.9 & 2.4 & - \\
\hline Manure **70 t/ha & 24.0 & 19.3 & 350 \\
\hline $\begin{array}{l}\text { Manure ** } 70 \text { t/ha + N } 90 \\
\mathrm{~K}_{90} \mathrm{P}\end{array}$ & 180 & 1.9 & 244 \\
\hline $\mathrm{N}_{120} \mathrm{P}_{90} \mathrm{~K}_{120}$ & & 0.49 & \\
\hline $\mathrm{NSR}_{05}$ & & & \\
\hline
\end{tabular}

** Manure -2 year aftereffect

The application of increased doses of mineral fertilizers doubled the increase in the yield of white mustard to $13.4 \mathrm{t} / \mathrm{ha}$. All the results obtained for the green mustard culture are quite convincing and reliable, since they are confirmed by mathematical processing.

Analyzing the yield data presented in Table 5, it can be noted that the aftereffect of the organic-mineral fertilization system on white mustard is quite effective, and the increase was $350 \%$. The aftereffect of clean manure was much lower and amounted to $44 \%$. The application of mineral fertilizers practically tripled the yield compared to the organic system and amounted to $244 \%$.

The yield data of winter wheat in 2019 was slightly lower than in 2018 for spring wheat, apparently, it was influenced not only by the predecessor, but also by the introduction of green manure in the form of white mustard instead of manure in 2019 (Table 6).

Table 6. Impact of different fertilization systems on winter wheat yield, 2019.

\begin{tabular}{|l|c|c|c|}
\hline \multirow{2}{*}{ Option } & \multirow{2}{*}{$\begin{array}{c}\text { Average } \\
\text { yield, t/ha }\end{array}$} & \multicolumn{2}{c|}{ Increase } \\
\cline { 3 - 4 } & 1.91 & t/ha & \% \\
\hline Control & 2.70 & 0.79 & 41 \\
\hline $\begin{array}{l}\mathrm{N}^{* * *} \text { Siderat }+\mathrm{N}_{120} \mathrm{P}_{90} \\
\mathrm{~K}_{120}\end{array}$ & 3.40 & 1.49 & 78 \\
\hline $\begin{array}{l}\mathrm{N}^{* * *}+\text { Siderat }+\mathrm{N}_{120} \mathrm{P} \\
90 \mathrm{~K}_{120}\end{array}$ & 2.94 & 1.03 & 54 \\
\hline $\begin{array}{l}\mathrm{N}_{120} \mathrm{P}_{90} \mathrm{~K}_{120}+\text { green } \\
\text { manure }\end{array}$ & & 0.27 & \\
\hline NSR 05 & & & \\
\hline
\end{tabular}

*** Manure - 3 year aftereffect

The aftereffect of the organomineral system increases the yield of winter wheat by $78 \%$ in relation to the control option (Table 8). Application of mineral fertilizers exceeded the aftereffect of manure and amounted to $54 \%$.

\section{Conclusion}

Use of organic and organomineral fertilization systems had a positive effect on the indicators of the physicochemical properties of sod-podzolic soils. In the control option, there was a gradual increase in soil acidity over the years. On fertilized options, the indicators of exchangeable acidity increased to 6.1 units, and the hydrolytic acidity of the soil decreased by $0.08 \mathrm{meq} / 100 \mathrm{~g}$ of soil.

The greatest effect on the exchange and hydrolytic acidity was exerted by the organic and organomineral fertilization systems during the study period: pHsal reached 5.86.1 units, and the hydrolytic level decreased by $0.49 \mathrm{meq} / 100 \mathrm{~g}$ of soil. 
Application of manure reduced the negative indicators of the decrease in the balance of $\mathrm{Ca}$ and $\mathrm{Mg}$ by $564 \mathrm{~kg} / \mathrm{ha}$ or by $83 \%$, and in the organomineral and mineral options by 64 and $39 \%$, respectively.

The best indicators of crop productivity of the crop rotation link were obtained from the organomineral fertilization system. The average yield increase in this option was $116 \%$ in relation to the control option. In the option with manure and mineral fertilizers - $69 \%$.

\section{References}

1. S. Alekseyeva, Agrokhimicheskiy vestnik, 3 (2002)

2. N. M. Belous, V. V. Mameyev, Ye. V. Smol'skiy (Izdatel'stvo Bryanskogo GAU, 2015)

3. T.I Volodina, A.I. Koryakina, Aktual'nyye voprosy agrarnoy nauki i obrazovaniya (2008)

4. T.I. Volodina, A.N. Levchenkova, G.A. Romanov, Agrochemistry, 3 (2014)

5. T.I. Volodina, A.N. Levchenkova, N.S. Bulynicheva, YU.V. Nekrasov, Nauka i obrazovaniye dlya ustoychivogo razvitiya territoriy (Materially regional'noy nauch.prakt. ekologicheskoy konferentsii, 2014)

6. O.V. Gladysheva, V.A. Svirina, O.A. Artyukhova, Plodorodiye, 119, 2 (2021)

7. I.A. Ivanov, V. Spasov, A. Ivanov (VGSKhA, 1998)

8. V. Mal'tsev, V. Moshkarev, Agrokhimiya, 4 (2000)

9. G. Merzlaya, R. Afanas'yeva, Pochvovedeniye, 8 (2005)

10. G.Ye. Merzlaya, M.N. Novikov, A.I. Yes'kov, S.I. Tarasov (Rossel'khozakademiyaGNU VNIPTIOU, 2006)

11. G.Merzlaya, Plodorodiye (2020)

12. A.M. Derzhavin, D.S. Bulgakov (VNIIA, 2003)

13. V. Mineyev, N. Gomanova, Agrokhimiya, 1 (2005)

14. Nebol'sin, Z. Nebol'sina, Agrokhimiya, 8 (2008)

15. V.V. Lapa, V.N. Bosak, Agrokhimiya, 5 (2006)

16. S.YA. Trofimov, A.V. Arzamazova, R.R. Kinzhayev, A.V. Khamutovskaya, M.M. Karpukhin, Vestnik Moskovskogo universiteta, Pochvovedeniye, 2 (2021)

17. D. Neina, Open Access publishing for the scientific community (2019)

18. D. L. Sparks (Acad. press, Cop., 2003)

19. H. Zhang, Oklahoma State University (2017)

20. W. Flaig, Proc. 3rd Int. Symp., 2 (1978) 